\title{
薬剤師の在宅医療推進のための症例検討プログラムの構築 一教育と臨床の融合一
}

\author{
吉武毅 人, ${ }^{*, a, b}$ 大澤友二c,d
}

\section{Establishing a Case-study Program for the Promotion of Home Medical Care of Pharmacists -Fusing Education and Clinical Support-}

\author{
Taketo Yoshitake ${ }^{*, a, b}$ and Tomoji Ohsawa ${ }^{c, d}$ \\ ${ }^{a}$ Daiichi University of Pharmacy; 22-1 Tamagawa-machi, Minami-ku, Fukuoka 815-8511, Japan: ${ }^{b}$ Health Care Center, \\ Kyushu Central Hospital; 3-23-1 Shiobaru, Minami-ku, Fukuoka 815-8588, Japan: 'Himawari Pharmacy; \\ 1-66 Momijigaoka-higashi, Kasuga, Fukuoka 816-0833, Japan: and ${ }^{d}$ Faculty of Pharmaceutical \\ Sciences, Kyushu University; 3-1-1 Maidashi, Higashi-ku, Fukuoka 812-8582, Japan.
}

わが国では急速な高齢化の伸展に伴い，在宅医療 の充実が急務となっている，在宅におけるチーム医 療を充実させるために，薬剤師による在宅医療への 参画が求められている。近年, 在宅での「訪問薬剂 管理指導」を行う薬局は年々増加しており, 薬棛師 による在宅での薬剤管理は進みつつある。2015 年 10 月に厚生労働省が示した「患者のための薬局ビ ジョン」においても, 今後, 地域包括ケアの構築に あわせて, かかりつけ薬剤師・薬局として備えるべ き機能の 1 つとして「在宅対応」が挙げられている.

このように, 薬剤師による在宅医療への参加が願 われているが，様々な疾病，家庭環境を抱えている 在宅患者に対し, 在宅医療に経験がない薬剤師が参 画するためには，事前の教育的アプローチが必要と なる，臨床教育において，患者の症例に基づく検討 を行うことは有用であるとされており，薬剤師が在 宅医療に参入する際にも, 症例検討を用いて疑似体 験することで取り組みが容易になると期待される. このためわれわれは, 大学での症例検討の経験と, 実際に在宅医療を取り組んでいる薬剤師の経験を融 合するため, 2014 年 5 月に第一薬科大学社会薬学 分野（現・地域医療薬学センター）に「教育用在宅

\footnotetext{
$a$ 第一薬科大学 (干815-8511 福岡市南区玉川町 22-1), $b$ 九州中央病院健康管理センター（广815-8588 福岡市 南区塩原 3-23-1), cひまわり薬局（干816-0833 福岡県 春日市紅葉ヶ丘東 1-66), ${ }^{d}$ 九州大学薬学部（干8128582 福岡市東区馬出 3-1-1)

*e-mail: t-yoshitake@daiichi-cps.ac.jp

日本薬学会第 136 年会シンポジウム S11 序文
}

症例作成ワーキングループ」（以下，WG）を設置 し, 大学教員と在宅医療に携わる薬剤師による症例 作成を行っている．現在までに，肺がん症例 2 例 (化学療法, ターミナルケア), 心不全症例 3 例（入 門編, 急性期, 慢性期), 糖尿病症例 2 例 (経口剂, インスリン使用）の 7 症例を作成している.

本シンポジウムでは, WG 活動に参加し, 大学 において地域医療教育を実践している大学教員と, 医療現場で在宅医療を実践している薬剂師をシンポ ジストとして迎え, 教育用症例作成による在宅医療 推進の課題について考察した. 最初に, 地域医療で の研修や医学教育の視点から, 地域医療支援病院で ある九州中央病院で医師として勤務している, 第一 薬科大学の吉武毅人氏に「教育用在宅症例作成ワー キンググループ』設置の背景」について講演頂いた.

次に, WG 活動を大学教員と薬凨師の視点から検 討するため, まず大学教員の立場から, 第一薬科大 学の小武家優子氏に「薬学教育における在宅医療教 育の現状とその課題」について, ついで, 在宅医療 に携わる薬剤師の立場から, 菜のはな薬局の古賀砂 登美氏に「在宅医療における薬剤師の現状とその課 題」について講演頂いた。最後に, 薬学生や薬剤師 を対象に実際にWGで作成した症例を用いた教育 活動を実施している, 九州大学薬学部非常勤臨床教 授でもある，ひまわり薬局の大澤友二氏に「在宅医 療における症例検討の役割と教育効果」について講 演頂いた.

これまでも, 薬剤師の在宅医療への参画に関する シンポジウムは種々行われてきたが, 今回のシンポ 
ジウムでは，在宅医療実践のための「在宅症例検討 による教育」に焦点を当てている．在宅症例による 臨床教育により，薬剤師の在宅医療への参画がさら
に推進されることを期待したい。なお本シンポジウ ムは「日本社会薬学会九州支部」より推薦を頂いた. 